\title{
THE EFFECT OF GLYCINE ON THE PRODUCTION AND EXCRETION OF URIC ACID ${ }^{1}$
}

\author{
By MEYER FRIEDMAN \\ (From the Harold Brunn Institute for Cardiovascular Research, Mt. Zion Hospital, \\ San Francisco, California)
}

(Received for publication November 28, 1946)

\section{INTRODUCTION}

Although most investigators ( 1 to 4$)$ have agreed that the ingestion of protein increases the output of uric acid in man, there has been no clear elucidation of the mechanism whereby this is accomplished. Mâres (5) believed that the increased uric acid in urine following high protein feeding resulted from the deterioration of nuclei of digestive cells concerned in the assimilation of the ingested protein. He offered in support of this theory the observation that atropine decreased and pilocarpine increased the output of uric acid. Taylor and Rose (1) found that, although urinary uric acid increased after an intake of high protein, the excretion of urinary creatinine did not change. Lewis, Dunn and Doisy (4) administered various amino acids to men in order to obviate as much as possible the probability of digestive gland activity necessarily involved in converting protein into its constituent amino acids. They found that all amino acids tested except sarcosine increased the output of uric acid. Since this latter amino acid was not catabolized in the body, the authors concluded that the uric acid metabolism of the body was increased by the specific dynamic action of catabolizing amino acids. Rose (6) concluded that the increase in uric acid output after high protein ingestion was due to generalized cellular stimulation occasioned by a higher caloric intake, thus implying that the increase in urinary uric acid was due to some intrinsic protein or amino acid effect. Christman and Mosier (7) gave glycine to subjects and observed an increased urinary uric acid but no change in the renal excretion of creatinine. They apparently concurred with Rose's theory concerning the general stimulating effect of protein or amino acids on cellular metabolism with consequently increased production and secondarily increased excretion of uric acid. Quick

\footnotetext{
1 Aided by a grant from the Dazian Foundation for
} Medical Research.
(8) also observed that glycine feeding increased uric acid excretion, particularly when combined with salicylate ingestion.

However, various observations have been made which cannot be fitted in with the theory of increased production of uric acid after ingestion of protein or amino acids. Thus, although Lewis, Dunn, and Doisy (4) implied that the specific dynamic action of ingested amino acids effected an increased production of uric acid, they also found that glutamic acid (an amino acid without significant dynamic action) increased uric acid output as markedly as any amino acid tested. Furthermore these investigators in this particular study never determined the concentration of uric acid in blood after ingestion of amino acids-it was assumed apparently that such a rise occurred because of the increased urinary output observed. Later however, Gibson and Doisy (9) were unable to detect a rise in blood uric acid in man after the ingestion of amino acids. Finally, Pitts (10) showed that an excess of an amino acid (glycine) might influence the renal excretion of a blood constituent not by increasing the production of the latter but by competing with it in the renal tubular reabsorptive process. These latter observations suggested the possibility that excess amino acid ingestion might increase urinary uric acid not by initially increasing the concentration of the latter in the blood but by interfering with its renal tubular reabsorption after its glomerular filtration (11).

In order to explore the validity of this last possibility as well as to determine other possible mechanisms involved in the increased excretion of uric acid after ingestion of amino acids, rats were given glycine. Studies then were made of the creatinine, hippurate and uric acid clearances together with the blood uric acid concentrations. Similar studies with the exception of the hippurate clearance were made on 2 human subjects. 
Finally studies were made of the blood concentration of uric acid in nephrectomized rats given glycine. The results of these studies suggested that glycine increased the output of uric acid by effecting initially a decrease in the amount of uric acid reabsorbed by the renal tubules.

\section{METHODS}

\section{A. Animal experiments}

\section{(1) Clearance and blood uric acid studies}

Nineteen male albino rats, approximately 6 months of age, fed Purina Dog Chow, were used in this study. Control creatinine and hippurate clearances were determined for $\mathbf{2}$ hours exactly as described in a previous study (12). However, uric acid studies were also made on the rats at the same time by allowing the total period of urine collection to continue past the 2 hours necessary for the above mentioned clearances until a period of 5 hours had been attained. The blood uric acid was determined on the initial and final blood samples taken for the creatinine and hippurate clearances as well as on a third blood sample taken at the end of the 5-hour collection period. The urine collected for 5 hours was analyzed also for uric acid. The blood uric acid clearance was calculated by determining the average uric acid output per hour and dividing this figure by the average blood uric acid concentration per $\mathrm{ml}$. over the 5 -hour period (determined by averaging the blood uric acid concentrations of the 3 blood samples taken). In this manner, the creatinine, hippurate, and uric acid clearance as well as the blood uric acid level were determined concomitantly although the uric acid clearance was calculated on a 5-hour collection period. After these control clearances had been made, they were repeated 1 week later on the same rats except that the latter were given $50 \mathrm{mgm}$. of glycine per 100 grams of body weight at the beginning of the collection period and $5 \mathrm{mgm}$. every hour for' 5 hours. The creatinine and hippurate clearances have been expressed in ml. of plasma per hour per 100 grams of body weight. The uric acid clearance was not found to vary with body weight, hence has been expressed in $\mathrm{ml}$. of blood per hour per rat.

Uric acid in blood was determined according to the method of Folin (13) except that proportionately smaller quantities of reagents were employed in order to determine the uric acid content of no more than $0.5 \mathrm{ml}$. samples of whole blood. Uric acid in urine was determined according to the method of Benedict and Franke (14).

\section{(2) Blood uric acid levels in nephrectomized rats}

Seventeen healthy rats were nephrectomized after control blood uric acid determinations had been made. Nine of these rats then received $100 \mathrm{mgm}$. of glycine by stomach tube immediately after operation and $50 \mathrm{mgm}$. 3 times a day as long as they lived. The remaining 8 rats received no glycine and served as controls. Blood samples were obtained daily from each rat and analyzed for uric acid. Water but not food was given to the rats.

\section{B. Human experiments}

Two healthy adult men (W. C., age 34 and M. F., age 36) previously on a purine-free diet for over 48 hours were studied. At 9:30 a.m., each subject was given 2.5 grams of creatinine in $500 \mathrm{ml}$. of $\mathrm{H}_{2} \mathrm{O}$. At 10:15 a.m., the first blood sample was taken and urine collection begun. Five hundred $\mathrm{ml}$. of $\mathrm{H}_{2} \mathrm{O}$ were taken every half hour for 4 hours. At 12:15 p.m. a second blood sample was taken and a final blood sample at 2:15 p.m., at which time urine collection ended. The first two blood samples were analyzed for both creatinine and uric acid but the third sample was analyzed for uric acid alone. One-half ml. of urine was obtained from the collecting jar at 12:15 p.m. and analyzed for creatinine and the urine collected for the entire period of 4 hours was analyzed for uric acid. Thus, a 2-hour creatinine and a 4-hour uric acid clearance were able to be obtained. The $0.5 \mathrm{ml}$. removed from the collection jar at the end of 2 hours, as in the rat experiments, was included in estimating the total volume (collected over the 4 hours) for the determination of uric acid clearances. Two weeks after these control studies had been made, the entire procedure was repeated on the same 2 subjects except that at the beginning of the collection period, each ingested 25 grams of glycine. Creatinine and uric acid clearances have been expressed in $\mathrm{ml}$. per minute.

\section{RESULTS}

\section{A. Effect of glycine on uric acid output and clear- ance of the rat}

The administration of glycine to rats over the 5hour clearance study was found (see Table I) to have increased the uric acid output of 17 of the 19 rats studied. The average uric acid output before glycine ingestion was $0.136 \mathrm{mgm}$. per hour and $0.170 \mathrm{mgm}$. per hour afterwards, an increase of approximately 25 per cent. Likewise the average uric acid clearance increased from $10.70 \mathrm{ml}$. to $14.50 \mathrm{ml}$. per hour, an increase of 35 per cent.

The average urine volume was observed to decrease (see Table I) from $3.90 \mathrm{ml}$. to $2.90 \mathrm{ml}$. per hour after glycine ingestion. The average creatinine clearance however showed no significant change being $34.3 \mathrm{ml}$. before and $35.4 \mathrm{ml}$. per hour after glycine had been given. The hippurate clearance also showed no significant change as it was $138 \mathrm{ml}$. before and $139 \mathrm{ml}$. per hour after glycine administration. It was clear from these studies then that the increase in uric acid output observed after glycine ingestion was due neither to in- 
EFFECT OF GLYCINE ON OUTPUT OF URIC ACID

TABLE I

The effect of glycine on the excretion of uric acid in the rat

\begin{tabular}{|c|c|c|c|c|c|c|c|c|c|c|}
\hline \multirow{2}{*}{ Rat } & \multicolumn{5}{|c|}{ Before glycine } & \multicolumn{5}{|c|}{ After glycine } \\
\hline & U.V.1 & C.C. ${ }^{2}$ & H.C. ${ }^{3}$ & U.A.E.4 & U.A.C.' & U.V. & c.c. & H.C. & U.A.E. & U.A.C. \\
\hline $\begin{array}{l}98 \\
75 \\
29 \\
72 \\
50 \\
43 \\
52 \\
42 \\
01 \\
89 \\
21 \\
88 \\
53 \\
29 \\
55 \\
90 \\
02 \\
39 \\
77\end{array}$ & $\begin{array}{l}1.8 \\
4.1 \\
4.4 \\
4.1 \\
3.9 \\
1.4 \\
2.5 \\
4.0 \\
4.2 \\
4.2 \\
3.9 \\
4.4 \\
5.1 \\
4.2 \\
4.7 \\
3.9 \\
4.4 \\
4.4 \\
4.6\end{array}$ & $\begin{array}{l}14.3 \\
46.8 \\
44.0 \\
34.6 \\
35.4 \\
14.2 \\
24.8 \\
35.5 \\
18.6 \\
34.6 \\
34.8 \\
43.7 \\
34.4 \\
28.5 \\
48.0 \\
38.8 \\
32.5 \\
50.5 \\
37.0\end{array}$ & $\begin{array}{r}110 \\
202 \\
175 \\
139 \\
147 \\
122 \\
87 \\
118 \\
91 \\
108 \\
146 \\
160 \\
158 \\
115 \\
256 \\
128 \\
73 \\
152 \\
138\end{array}$ & $\begin{array}{l}.101 \\
.134 \\
.157 \\
.163 \\
.162 \\
.132 \\
.115 \\
.161 \\
.144 \\
.139 \\
.137 \\
.141 \\
.139 \\
.110 \\
.114 \\
.113 \\
.134 \\
.172 \\
.130\end{array}$ & $\begin{array}{r}6.75 \\
10.30 \\
14.30 \\
15.10 \\
11.80 \\
9.50 \\
12.90 \\
15.30 \\
9.60 \\
9.50 \\
10.10 \\
9.10 \\
9.90 \\
9.40 \\
8.80 \\
9.00 \\
9.30 \\
10.60 \\
12.90\end{array}$ & $\begin{array}{l}2.9 \\
3.5 \\
3.7 \\
1.3 \\
2.4 \\
2.7 \\
3.5 \\
1.2 \\
4.1 \\
3.2 \\
3.4 \\
2.7 \\
2.5 \\
2.5 \\
2.9 \\
2.6 \\
2.9 \\
3.6 \\
3.6\end{array}$ & $\begin{array}{l}35.0 \\
40.0 \\
39.2 \\
28.0 \\
31.4 \\
31.7 \\
46.3 \\
23.9 \\
48.0 \\
28.6 \\
38.6 \\
24.7 \\
40.8 \\
20.8 \\
29.9 \\
39.7 \\
45.7 \\
43.8 \\
36.8\end{array}$ & $\begin{array}{r}\overline{146} \\
157 \\
180 \\
- \\
\overline{-} \\
- \\
\overline{119} \\
\overline{108} \\
142 \\
64 \\
160 \\
129 \\
81 \\
191 \\
192\end{array}$ & $\begin{array}{l}.173 \\
.168 \\
.206 \\
.175 \\
.187 \\
.210 \\
.176 \\
.199 \\
.151 \\
.127 \\
.175 \\
.208 \\
.178 \\
.184 \\
.138 \\
.128 \\
.125 \\
.158 \\
.164\end{array}$ & $\begin{array}{r}15.00 \\
16.30 \\
19.50 \\
15.40 \\
18.30 \\
16.20 \\
14.70 \\
15.00 \\
12.30 \\
9.80 \\
12.80 \\
19.60 \\
11.90 \\
14.90 \\
11.70 \\
10.70 \\
10.40 \\
14.10 \\
17.10\end{array}$ \\
\hline Av. & 3.9 & 34.3 & 138 & .136 & 10.70 & 2.9 & 35.4 & 139 & .170 & 14.5 \\
\hline
\end{tabular}

$1 \mathrm{U}$. V. equals urine volume in $\mathrm{ml}$. per hour.

2 C. C. equals creatinine clearance in ml. per hour per 100 grams body weight.

$2 \mathrm{H}$. C. equals hippurate clearance in $\mathrm{ml}$. per hour per 100 grams body weight.

U. A. E. equals milligrams of uric acid excreted in urine per hour.

- U. A. C. equals uric acid clearance in ml. per hour.

creased glomerular filtration nor to increased renal blood flow.

\section{B. Effect of glycine on blood uric acid of the rat}

Uric acid content of rat's blood was found to increase from 10:00 a.m. to 3:00 p.m. (the hours employed for the clearance studies) in the control rats. Thus (see Table II) the control average blood uric acid was $0.97 \mathrm{mgm}$. at the beginning of the clearance study, $1.16 \mathrm{mgm}$. at the end of 2 hours and $1.51 \mathrm{mgm}$. per $100 \mathrm{ml}$. at the end of 5 hours. Similarly the blood uric acid was found to increase in those rats given glycine (see Table II), but the increase was not greater than in the control animals. There was little evidence, then, from these results to support the assumption that glycine per se increased the production of uric acid in the animal body.

The evidence obtained from the nephrectomized rats fed glycine also failed to support the assumption that more uric acid was produced or mobilized in the blood stream following increased intake of amino acid. Thus the average blood uric acid level of 8 control rats before nephrectomy was 1.85 mgm. per $100 \mathrm{ml}$. of blood. Twenty-four hours after nephrectomy the blood concentration was $1.88 \mathrm{mgm}$. and $1.96 \mathrm{mgm}$. per $100 \mathrm{ml}$. after 48 hours. This represented an increase of 6 per cent in the blood uric acid 48 hours after nephrectomy. The average blood uric acid content of 9 rats given glycine following nephrectomy was $1.71 \mathrm{mgm}$. per $100 \mathrm{ml}$. before and $1.80 \mathrm{mgm}$. and $1.84 \mathrm{mgm}$. per $100 \mathrm{ml} ., 24$ and 48 hours, respectively, after nephrectomy, representing an increase of but 8 per cent. In short, glycine feeding did not significantly increase the blood uric acid of nephrectomized rats. It must be remembered, however, that the rat converts uric acid into allantoin. It is therefore possible that any excess uric acid produced in these nephrectomized rats may have been converted so quickly to allantoin that no rise in blood uric acid occurred. Accordingly, the experimental data obtained on these nephrectomized rats are not necessarily applicable to human subjects.

\section{The effect of glycine on uric acid output and clearance of man}

The ingestion of 25 grams of glycine by 2 subjects was found to increase the uric acid output of both. The average uric acid output (see Table 
TABLE II

The effect of glycine on the blood uric acid of the rat

\begin{tabular}{|c|c|c|c|c|c|c|}
\hline \multirow{3}{*}{ Rat } & \multicolumn{3}{|c|}{ Normal rat } & \multicolumn{3}{|c|}{ Normal rat given glycine* } \\
\hline & 10:00 a.m. & $12: 00 \mathrm{n}$. & 3:00 p.m. & 10:00 a.m. & $12: 00 \mathrm{n}$. & 3:00 p.m. \\
\hline & $\begin{array}{l}\text { Uric } \\
\text { acid }\end{array}$ & $\begin{array}{l}\text { Uric } \\
\text { acid }\end{array}$ & $\begin{array}{l}\text { Uric } \\
\text { acid }\end{array}$ & $\begin{array}{l}\text { Uric } \\
\text { acid }\end{array}$ & $\begin{array}{l}\text { Uric } \\
\text { acid }\end{array}$ & $\begin{array}{l}\text { Uric } \\
\text { acid }\end{array}$ \\
\hline & $\underset{\text { per cent }}{\text { mgm. }}$ & $\underset{\text { per cent }}{\operatorname{mgm} .}$ & $\underset{\text { per cent }}{\operatorname{mgm} .}$ & $\underset{\text { per cent }}{\operatorname{mgm} .}$ & $\underset{\text { per cenl }}{\operatorname{mgm} .}$ & $\underset{\text { per cent }}{\text { mgm. }}$ \\
\hline 98 & 1.30 & 1.60 & 1.60 & 0.97 & 1.10 & 1.40 \\
\hline 75 & 1.20 & 1.30 & 1.40 & 0.94 & 1.30 & 0.86 \\
\hline 29 & 0.81 & 1.10 & 1.40 & 1.10 & 0.97 & 1.10 \\
\hline 72 & 0.95 & 1.00 & 1.30 & 0.83 & 1.50 & 1.10 \\
\hline 50 & 0.92 & 1.30 & 1.90 & 0.94 & 0.91 & 1.20 \\
\hline 43 & 1.00 & 1.30 & 1.80 & 1.00 & 1.10 & 1.80 \\
\hline 52 & 0.81 & 0.95 & 0.92 & 0.90 & 1.10 & 1.60 \\
\hline 42 & 0.75 & 1.00 & 1.40 & 1.00 & 1.20 & 1.80 \\
\hline 01 & 0.84 & 0.95 & 1.40 & 1.10 & 1.30 & 1.30 \\
\hline 89 & 0.75 & 0.92 & 1.50 & 1.00 & 1.30 & 1.60 \\
\hline 21 & 0.84 & 0.73 & 1.30 & 1.00 & 1.20 & 1.90 \\
\hline 88 & 1.10 & 1.00 & 2.00 & 0.68 & 1.00 & 1.50 \\
\hline 53 & 1.20 & 1.20 & 1.60 & 0.61 & 1.40 & 2.50 \\
\hline 20 & 0.95 & 1.00 & 1.40 & 0.90 & 1.80 & 1.90 \\
\hline 55 & 1.00 & 0.96 & 1.60 & 0.65 & 1.10 & 1.80 \\
\hline 90 & 0.77 & 1.50 & 1.50 & 0.97 & 1.40 & 1.20 \\
\hline 02 & 1.40 & 1.50 & 1.40 & 0.90 & 1.20 & 1.50 \\
\hline 30 & 0.97 & 1.80 & 2.10 & 0.87 & 1.20 & 1.30 \\
\hline 77 & 0.93 & 1.00 & 1.10 & 0.92 & 0.97 & 1.00 \\
\hline Av. & 0.97 & 1.16 & 1.51 & 0.91 & 1.21 & 1.44 \\
\hline
\end{tabular}

* Each rat given $50 \mathrm{mgm}$. of glycine per 100 grams body weight at start and then $5 \mathrm{mgm}$. every hour of the 5-hour study period.

III) was $23.40 \mathrm{mgm}$. before and $39.95 \mathrm{mgm}$. per minute after the administration of glycine (an increase of 71 per cent). Similarly, the average uric acid clearance increased from $11.90 \mathrm{ml}$. to $17.50 \mathrm{ml}$. per minute (an increase of 47 per cent).

As was observed in the rats, the average urine volume also decreased (see Table III) from 3.26 $\mathrm{ml}$. before to $2.49 \mathrm{ml}$. per minute after glycine. The average creatinine clearance also decreased from $116.0 \mathrm{ml}$. before to $100.0 \mathrm{ml}$. per minute after glycine had been given. Similar again to the rat study, no significant change was observed in the blood uric acid level after glycine had been given.

\section{DISCUSSION}

The above results suggest quite strongly that glycine does not increase the production of uric acid in the body of either rat or man. On the other hand it was certain from the observations made that glycine ingestion does increase the renal excretion of uric acid, despite the fact that both creatinine and hippurate studies demonstrate the fact that there is neither increase in the rate of glomerular filtration nor in the renal blood flow after glycine. As a matter of fact, the creatinine clearance slightly decreased after glycine in the 2 human subjects tested. These facts lead to the inescapable conclusion that glycine in some manner probably impedes tubular reabsorption of the uric acid contained in tubular fluid. In other words, uric acid output is increased after glycine, not because the blood contains more uric acid nor because the kidney filters or secretes more of it, but because the renal tubule does not reabsorb the usual quantity of uric acid in the presence of excess glycine. The latter may compete with uric acid for reabsorption at the identical tubular site. This mechanism may be quite similar to that postulated by Pitts (10) to explain the preferential tubular reabsorption of glycine with impedance of creatine reabsorption when both are in the glomerular filtrate. Such a mechanism would explain also the fact that, in the present study, there was not the expected change in the rat's creatinine clearance commensurate with the decrease in urine volume (12) - a phenomenon which suggests increased water reabsorption by the tubule.

TABLE III

The effect of glycine on blood uric acid and uric acid excretion in man

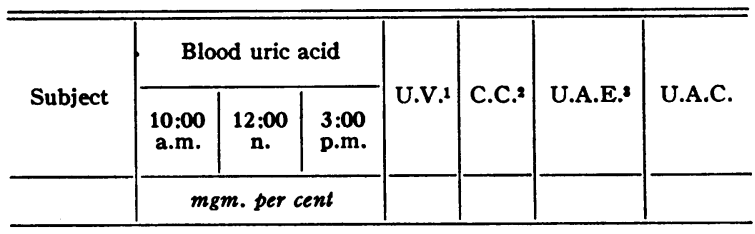

Before glycine

\begin{tabular}{|c|c|c|c|c|c|c|c|}
\hline $\begin{array}{l}\text { M. F. } \\
\text { W. C. }\end{array}$ & $\begin{array}{l}3.20 \\
3.40\end{array}$ & $\begin{array}{l}3.10 \\
3.40\end{array}$ & $\begin{array}{l}3.10 \\
3.50\end{array}$ & $\begin{array}{l}3.95 \\
2.56\end{array}$ & $\begin{array}{l}115 \\
118\end{array}$ & $\begin{array}{l}19.20 \\
27.60\end{array}$ & $\begin{array}{l}10.30 \\
13.50\end{array}$ \\
\hline Average: & 3.30 & 3.25 & 3.30 & 3.26 & 116 & 23.40 & 11.90 \\
\hline \multicolumn{8}{|c|}{$\begin{array}{l}\text { After glycine } \\
\text { (25 grams) }\end{array}$} \\
\hline $\begin{array}{l}\text { M. F. } \\
\text { W. C. }\end{array}$ & $\begin{array}{l}3.60 \\
4.00\end{array}$ & $\begin{array}{l}3.60 \\
3.90\end{array}$ & $\begin{array}{l}3.90 \\
3.90\end{array}$ & $\begin{array}{l}2.50 \\
2.48\end{array}$ & $\begin{array}{l}100 \\
101\end{array}$ & $\begin{array}{l}35.60 \\
44.30\end{array}$ & $\begin{array}{l}16.10 \\
18.90\end{array}$ \\
\hline Average: & 3.80 & 3.75 & 3.90 & 2.49 & 100 & 39.95 & 17.50 \\
\hline
\end{tabular}

${ }^{1} \mathrm{U}$. V. equals urine volume in $\mathrm{ml}$. per minute.

2 C. C. equals creatinine clearance in ml. per minute.

$3 \mathrm{U}$. A. E. equals milligrams of uric acid excreted in urine per minute.

4 U. A.C. equals uric acid clearance in ml. per minute.

- Glycine given after the 10:00 a.m. blood sample had been obtained. 
The failure of the blood uric acid to decrease in the presence of this increased renal output of uric acid may well be due to the ability of the extravascular tissues to maintain the blood uric acid concentration despite its increased renal excretion.

\section{SUM MARY}

The administration of glycine to the rat and to man was found to increase the renal excretion of uric acid without a concomitant change in either the renal hemodynamics or in the concentration of uric acid in the blood. Furthermore, glycine feeding was not found to increase the uric acid content of nephrectomized rats' blood.

These findings suggested the probability that glycine increased the excretion of uric acid by impeding its renal tubular reabsorption.

The author wishes to express his thanks for the technical assistance given to him by: Barbara Trousdale, Francis Greenberg, William Cano, Dr. Morton Garfield, and Zora Gross.

\section{BIBLIOGRAPHY}

1. Taylor, A. E., and Rose, W. C., The influence of protein intake upon the formation of uric acid. J. Biol. Chem., 1914, 18, 519.

2. Mendel, L. B., and Stehle, R. L., The rôle of the digestive glands in the excretion of endogenous uric acid. J. Biol. Chem., 1915, 22, 215.

3. Benedict, S. R., Uric acid in its relations to metabolism. Harvey Lectures, 1915, Series XI, 346.

4. Lewis, H. B., Dunn, M. S., and Doisy, E. A., Studies in uric acid metabolism. II. Proteins and amino acids as factors in the stimulation of endogenous uric acid metabolism. J. Biol. Chem., 1918, 36, 9.

5. Mares, F., Der physiologische protoplasmastoffwechsel und die purinbildung. Arch. f. d. ges. Physiol., 1910, 134, 59.

6. Rose, W. C., The influence of food ingestion upon endogenous purine metabolism. J. Biol. Chem., 1921, 48, 563.

7. Christman, A. A., and Mosier, E. C., Purine metabolism. II. The effect of the ingestion of glycine on the excretion of endogenous uric acid. J. Biol. Chem., 1929, 83, 11.

8. Quick, A. J., The relationship between chemical structure and physiological response. IV. Conjugation of salicylic acid with glycine and its action on uric acid excretion. J. Biol. Chem., 1933, 101, 475.

9. Gibson, H. V., and Doisy, E. A., A note on the effect of some organic acids upon the uric acid excretion of man. J. Biol. Chem., 1923, 55, 605.

10. Pitts, R. F., A renal reabsorptive mechanism in the dog common to glycine and creatine. Am. J. Physiol., 1943, 140, 156.

11. Bordley, J., and Richards, A. N., Quantitative studies of the composition of glomerular urine. VIII. The concentration of uric acid in glomerular urine of snakes and frogs determined by an ultramicroadaptation of Folin's method. J. Biol. Chem., 1933, 101, 193.

12. Friedman, M., The creatinine, inulin and hippurate clearances in the rat. Am. J. Physiol., 1947, 148, 387.

13. Folin, O., An improved method for the determination of uric acid in blood. J. Biol. Chem., 1930, 86, 179.

14. Benedict, S. R., and Franke, E., A method for the direct determination of uric acid in urine. J. Biol. Chem., 1922, 52, 387. 